\title{
TIN FOR OPIUM, OPIUM FOR TIN?
}

The early history of a Billiton Mining Company (BM) is of interest here for two questions: what is the relation between tin production and opium, and how does this concern the dependency/independency of the private industry on the Dutch colonial state. ${ }^{1}$ That from this early industrial activity it ultimately developed into the largest mining company in the world today, BHP-Billiton, is another rather complicated story. This is, of course, an interesting fact, but irrelevant here. ${ }^{2}$

Until the middle of the 19th-century, these foreign mining activities were only a matter of what was called the "Dutch Government in the East Indies" and the "English Government in Malacca". Tin mining was done at least from around 1700 onwards when the Sultan of Palembang, also ruler of the islands of Banca (Bangka, etc.) and Billiton (Beilitung, etc.), already had serious quarrels about tin with English and Dutch merchants. There were some loose contacts between the VOC and the islands: from 1640 onwards there is some trade between Batavia and Billiton (iron in the form of little axes and knifes exchanged for textiles).

Twenty-five years later, some people asked the VOC to protect them against the Sultan, but the islands were soon abandoned to what was called "pirates". ${ }^{3}$ From 1709 the Sultan delivered sufficient tin to Batavia at a fixed price in a regular way, apparently to keep the Dutch out of the region.

At the beginning of the 19th-century, the English reported that potentially 40-50,000 piculs at a cost price of 10 Spanish dollars per picul could be sold in China for 22 to 26 dollars. The EIC could make much more of it, 'if the Company were to monopolize the whole supply, the price might be raised at whim'. ${ }^{4}$ At this time the population of Banca was estimated at 10,000, of which 2,000 were Chinese, who worked the tin mines exclusive-

1 The official name in Dutch was: Naamloze Vennootschap Billiton Maatschappij (Billiton Company Ltd.). For the following history, I used M. Gruythuysen-R. Kramer, G. A. de Lange, J. Loudon, J. Mollema, F. Stapel, C. Swaving, R. Verbeek.

2 See an interesting article about the present BHP Billiton in The Economist, 21-8-2010.

3 F. Stapel, p. 14-25.

4 Idem, p. 29. 
ly. They were organized in so-called kongsehs or kongsis. If, so expected Raffles, the British took over the management of the island, Chinese would 'flock in great numbers to Banca'.

After the English disappeared, the Dutch started their conquering program. The Sultan of Palembang was defeated by General De Kock (1821). The latter bought the support of the "pirates" in the region, nominated an indigenous ruler and occupied Billiton as well by forming a military establishment of 50 soldiers. Chinese from Banca were imported into Billiton to teach the population how to mine tin.

The Dutch began tin-mining in the "governmental" Banca Tinwinning (BTW) from the 1820 s onwards; Billiton, still seen as a pirate nest, was too wild for them.

The tin was usually auctioned in Amsterdam. Batavia got its fee for this "service" also. Batavia, indeed, earned a great deal of money by doing nothing: just in the years $185^{2-1881}$ this amounted to nearly 110 million guilders from the tin source only! In this period the net profit per "gross picul" was not 26 dollars, as envisaged by the English, but already 75 guilders. ${ }^{5}$

The Chinese captain Tan Hang Kwee, one of the leaders of the Chinese tin-miners on Banca, concluded a contract with the Dutch (1827) to start tin mining on Billiton as well. ${ }^{6}$ This Chinese leased a concession 'at his own risk and expense', starting with 300 laborers. The Dutch guaranteed their safety, although everything had to be paid for by the Chinese, who had to look for collaboration with the indigenous population. The tin had to be sold exclusively to the Dutch government, which paid over four years a price of 12 Spanish dollars per picul, assuming that the market price was not lower than 20 dollars p.p. The Chinese were obliged to pay for housing and food for the 40-50 soldiers stationed on Billiton. Article 16 says that for the time of the contract, the Dutch shall not introduce 'the amphioen, arak and gambling licenses on Billiton'. Indeed, without the Chinese, neither the colonial state on Banca nor later BM could mine tin; they both had to buy the tin from kongsis at fixed prices.

The Chinese first discovered tin ore on Billiton ${ }^{7}$. They did not ask for money in advance, as was usual; everybody was happy, including King William I who signed the contract. A Dutch Minister in the Netherlands,

5 G. de Lange, p. 30 note. To provide an idea of the change in value is not easy, but this could be helpful: around $185^{\circ} \$ 26$ is worth $£_{5.33}$ and 75 guilders around $£_{7.5}$.

6 For this contract see F. Stapel, p. 66-74.

7 See J. Loudon, p. 9. 
however, acted the spoil-sport. He did not understand the way things worked on these islands. This man warned that now the Chinese could handle the tin-mining business for themselves, 'the old evil, the piracy and smuggling' will return. This ungrounded suspicion led to new measures imposed by the Governor-General in Batavia, to a new Dutch inspector on Billiton and even to the dismissal of Tan Hang Kwee (1829). This muddling through continued on for two decades. ${ }^{8}$

In the meantime the name "Nederlandsch Oost-Indië" ("Dutch East Indies") was invented as a consequence of the wave of conquests in the archipelago. ${ }^{9}$ As Minister of Colonies, Baud started procedures to make it possible for European private companies also to start mining activities in the archipelago. As a result, BTW remained on Banca running a Dutch public mine while on the neighboring island, Billiton, Dutch private interests could start with a license from the Dutch colonial government.

The trigger to this activity was His Royal Highness Prince Henry, who wanted to invest much money in tin mining on Biliton together with another aristocrat. ${ }^{10}$ The will of a member of the House of Orange could not be negated. The clever John Loudon became his representative, who was the public enemy of the representative of the Dutch in Batavia, the bureaucrat Croockewit. The latter told everybody that there was no tin on Billiton, but Loudon easily and quickly proved him wrong. Apparently, Batavia feared to lose its lucrative tin-business with the Chinese.

That was a well-grounded fear: in $185^{2}$ the first 500 picul of tin were mined. Eight years later very rich deposits were found along the east coast

8 Happily for the Chinese, the stupidity on the side of the Dutch was unbelievable since there exists as well an accompanying report from the local Dutch official about the contract with Tan Hong Kwee, which stipulates that the advantage of the contract is wholly on the side of the Dutch and that at least a hundred thousand guilders per year can be gained from the Chinese labor. See Idem, p. 123.

9 Earlier people used sometimes "Dutch India" (1653), but whether this referred to some "imperial drive" remains to be seen. Therefore, it should have been an official name used by the Directors of the VOC Amsterdam or a Dutch government. This was not the case. See F. Gaastra (2000), p. 8.

10 The initial investment capital was five million guilders. Prince Henry spent $2 / 5^{\text {th }}$ of it, Baron Van Tuyll van Serooskerken another $2 / 5^{\text {th }}$ and John Loudon $1 / 5^{\text {th. These people }}$ also issued shares of 1000 guilders among 35 mainly aristocratic friends. Prince Henry had 600 of these shares and apparently he expected to get 124,000 guilders interest per year. However, another aristocratic shareholder, Beelaerts van Blokland, earned a profit of 530,000 in 1882 which was increased to 701,000 ten years later. See R. Verbeek, p. 9. This must be his personal profit since the net profit of Batavia in 1882 was 179,130 which is $10 \%$ of the net profit of the company. One may suppose that the "costs" of the shareholders had already been deducted from this net profit. For the profit debate, see also G. de Lange, p. 25 ff., and for all the details of the royal contract, Idem, appendix b. 
of the island, which gave BM a bright future as a company and Batavia received the crumbs of the cake. Even they were worth a lot of money as the table below shows.

The Dutch "government" license was an expensive one: $10 \%$ of the net profit + export duties, import duties, auction costs, many other taxes and ... opium costs. The table gives part of the result for the whole district, which is similar to the island of Billiton, including the BM. Roughly onethird of the total payments had to be paid by the indigenous population, the rest by BM. This costly license is a reproduction of the permanent tensions between the very greedy Batavia bureaucrats (themselves always in conflict with Dutch bureaucrats in Holland) and the private interests, whether the so-called smugglers, foreigners or Dutch private interests.

Table 11. 'Contributions to the Dutch Indies Government by the Billiton District' (in guilders) ${ }^{11}$

\begin{tabular}{cccccc}
\hline Year & $\begin{array}{c}\text { Government } \\
\text { part of BM } \\
\text { profit } \\
(\mathrm{a})\end{array}$ & $\begin{array}{c}\text { Opium } \\
\text { income }\end{array}$ & $\begin{array}{c}\text { Taxes and } \\
\text { other } \\
\text { expenses } \\
(\mathrm{b})\end{array}$ & $\begin{array}{c}\text { Export duty } \\
(\mathrm{b})\end{array}$ & $\begin{array}{c}\text { Total } \\
\text { Payments to } \\
\text { government } \\
(\mathrm{e})\end{array}$ \\
\hline 1864 & --- & 14500 & 44910 & 12463 & 44910 \\
1870 & 75161 & 32400 & 154913 & 73575 & 230074 \\
1875 & 90598 & 110000 & 303051 & 123882 & 393649 \\
1880 & 164338 & 123600 & 427501 & 169033 & 591839 \\
1885 & 123873 & 247152 & 599718 & 152865 & 723591 \\
1890 & 155153 & 223100 & 679462 & 183977 & 834615 \\
1895 & 360896 & 204000 & 622244 & 166014 & 983140 \\
1900 & 4333615 & 180000 & 527202 & 175000 & 4860817 \\
1905 & 2278259 & 180012 & 516965 & 154000 & 2795224 \\
\hline
\end{tabular}

$11 \mathrm{~J}$. Mollema, appendix 4. Only a part of this appendix is reproduced in the text; it, furthermore, describes taxes paid by Chinese and Europeans working in BM, the direct tax paid by the indigenous people, auction costs, etc. In addition, it provides the data per year. Mollema was nearly the Chief Administrator of BM after 1900. Later the Directors of BM complained about the 'weak spots' in Mollema's book. See F. Stapel, p. 7. Probably they were referring to this table with mistakes: in the 1864 row (c) and (e) are the same, which is impossible; all the numbers ending in "ooo" must be dubious; the comment given on column (a) is not very clear: for several years $3 \%$ is paid by BM in natura (in tin, one may suppose), but are the data given equivalent to the $3 \%$, or the $7 \%$ cash or the full $10 \%$ ? Let's suppose it is the last percentage, because then it is easy to determine the full net profit of BM: the substantial amount of 620 million guilders or on average 11 million a year split among the few shareholders. For other amounts see J. Loudon, p. $111 \mathrm{ff}$. 
Table 11. Continued

\begin{tabular}{lccccc}
\hline Year & $\begin{array}{c}\text { Government } \\
\text { part of BM } \\
\text { profit } \\
(\mathrm{a})\end{array}$ & $\begin{array}{c}\text { Opium } \\
\text { income }\end{array}$ & $\begin{array}{c}\text { Taxes and } \\
\text { other } \\
\text { expenses } \\
\text { (c) }\end{array}$ & $\begin{array}{c}\text { Export duty } \\
\text { (d) }\end{array}$ & $\begin{array}{c}\text { Total } \\
\text { Payments to } \\
\text { government } \\
(\mathrm{e})\end{array}$ \\
\hline 1910 & 1230995 & 275229 & 742673 & 150000 & 1973668 \\
1915 & 881949 & 440000 & 1095954 & 183000 & 1977903 \\
1920 & 2560577 & 634000 & 1209438 & 274000 & 3770015 \\
& --- & --- & --- & --- & -- \\
TOTAL & 62793954 & 11709029 & 33515933 & 8570470 & 96309887 \\
\hline
\end{tabular}

(a) from $1865-1891 \mathrm{BM}$ had to give $10 \%$ of the profit, of which it gave $3 \%$ in natura;

(b) in 1909 the Opiumregie (see below) became effective on the island of Billiton; before that date the amounts concern the lease payments;

(c) a total of several taxes (income tax; tax on Chinese workers; patent tax, etc.);

(d) paid partly by BM and partly by the tin-buyers in Batavia;

(e) total of (a), the direct contributions, plus (c) the indirect contributions.

Opium, $11 \%$ of the total, was the single most important income for Batavia after the tin license. How and whether these opium costs were divided between $\mathrm{BM}$ and the indigenous population remains unknown. The following could give us a clue. Without going into great detail, the important role of the Chinese laborers must be stressed again.

From the beginning of tin production, the Chinese played a prominent role. They were, in fact, their own boss under the leadership of one or more captains. In Banca they did all of the work in a technical, social and commercial sense. Twenty years later, however, they were free laborers under the amateur leadership of white Batavia bureaucrats on Banca and aristocrats imported from Holland on Billiton. The former were apparently too greedy to invest, the latter were only interested in as high a dividend as possible. For the Chinese this did not make much difference.

On Billiton their housing situation was miserable, as the medical doctor Swaving explained. ${ }^{12}$ In the months of February and March 186o, some 700 Chinese miners died, mainly from beriberi (a deficiency of thiamine,

12 C. Swaving, p. $1 \mathrm{ff}$. In full detail he sketched the building (kongsi house of $30 \times 10 \times 5$ $\mathrm{m})$ in which 200 Chinese lived, with one entrance and no windows or other ventilation possibilities. Per person they had 7.5 meter at their disposal, 'which is only one-sixth of what they deserve'. Every year beriberi decimated the Chinese population. When more profitable deposits were found, around 1870, this situation was alleviated. For the serious labor conditions in the tin mines of Malaya, see C. Trocki (1990), p. 67 ff.; B. Watson Andaya, L. Y. Andaya, p. 135 ff. 


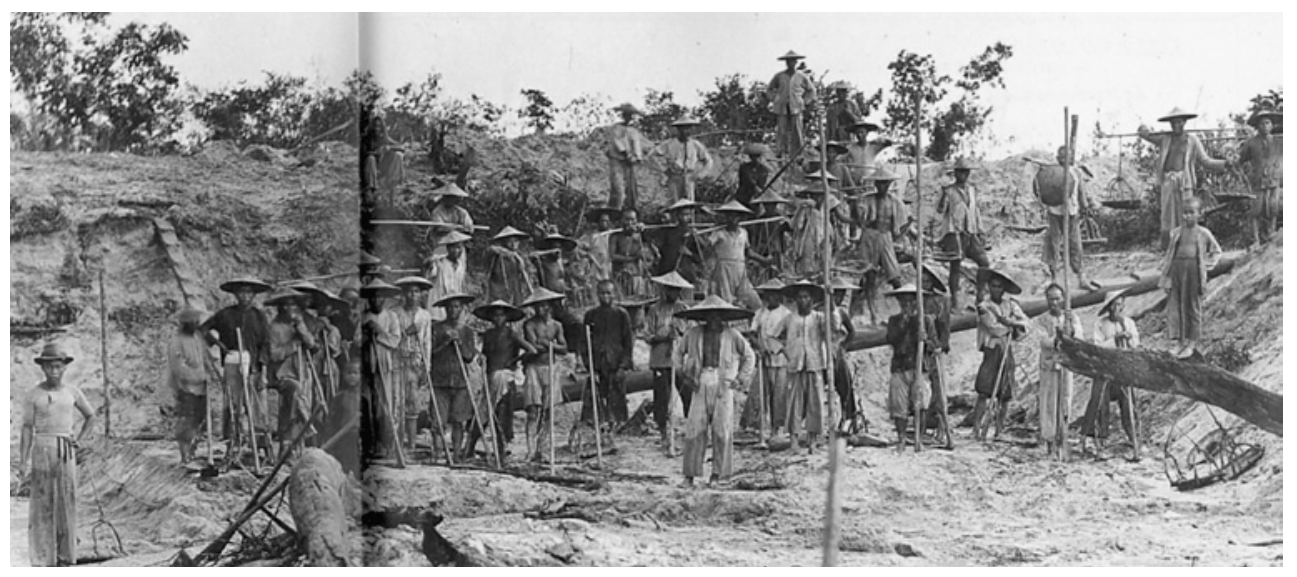

Ill. 17. Coolie Labor in the Dutch Tin Mines, 1919

Source: B. Manders, 2010; Historisch Nieuwsblad, September 2010. Chinese "coolies" had to work under "strangle contracts" and severe circumstances in mines, along railways or on plantations. The picture shows a tin mine on the island Banca or Billiton. The East Indies were also "governed" by racism with the notorious rule: "The more pigment, the less payment.'

vitamin $B_{1}$, in the diet). Five years later 60 Chinese died in a week or $63 \%$ of the workforce in a month.

Swaving also pointed to the very muddy and wet work of tin miners, the poisonous miasma and starvation. ${ }^{13}$ All this together must have debilitated their stamina. In the Billiton administration the column next to the one giving dividend per share indicates the 'Mortality Percentage of the Miners'. ${ }^{14}$

In the initial period of BM, the workers were paid 20 guilders per picul of pure tin as the market price was three or four times as much. This amount must have taken several days of work for one person. Later they were paid much less: around 300 guilders per year (from 1900-1918 even on average 280). This is equivalent to less than one guilder per day. BM's notorious administrators had many possibilities to exploit these mostly

13 C. Swaving, p. 4, 5 .

$14 \mathrm{~J}$. Mollema, appendix 3. The percentage was $6-23 \%$ per year in the 1850 ; this decreased to around $10 \%$ in the 1870 s and further to $2-3 \%$ per year. That looks beneficial, but the number of the Chinese miners increased quickly from about 600 in the $1855 \mathrm{~s}$ to about 2,500 in the 1870 s, to 8,000 in the 188 os, 11,000 in the 1890 s and 28,990 in 1920 . In these last few years the mortality was $1-2 \%$, which is still about 300 Chinese workers every year! At that time, 70 years after the establishment of BM, about 15,000-17,000 Chinese tin miners must have perished on this island of Billiton. The rest was exploited to the maximum. 
immigrant workers. ${ }^{15}$ The mentality of the new Dutch management is demonstrated as Loudon noted in his diary:

27th August. ... According to Dekker the Chinese are found and brought by Tuyll; bad people; Hokloh Chinese; fighting, opium smoking and gambling. He says it is difficult to keep discipline among them. In addition, there is much too much paid for them ... The Chinese do not want to eat the rice bought by Tuyll ... this is investigated and indeed confirmed. [New rice] is procured with a $15 \%$ loss; also too expensive. ${ }^{16}$

This greedy Dutch leadership itself started to crimp immigrating Chinese. Another day Loudon brought the following salute to the dying Chinese. He discovered on his inspection tour that Chinese were playing the "poh"game:

[I] threatened them with strokes by the stick [rotting] if they did it again. A few sick Chinese were dying. At Rembing everything looked sad. The kongsi-house was full of sick and dying Chinese; most of them had large, dirty wounds on their legs; these do not come from the climate ... and certainly not from the heavy work, because they are too lazy to work; anyway, this doing nothing will last some days and then it's over and out. ${ }^{17}$ (italics by Loudon)

None of this is reported about the situation on Banca for whatever reason.

In the 188 os a big row in the Dutch parliament was organized about the old animosity: BM as a company for the benefit of the colony and eventually the Dutch state (say the Batavia-The Hague bureaucrats) or

15 For these data, see J. Mollema, appendix 3. His explanation of the annual payments (Idem, p. 157 ff.) is far from convincing, but it is not my duty to discuss the case. Anyway, in his BM memorial book, he still proudly remembers that in 1920/21, 974 miners returned to China with savings of 386,388 guilders or about 400 guilders per person after three years of hard labor (Idem, p. 156, 157)! A hilarious story describes how once BM had good luck, because the rate of the dollar had declined from 2.55 to 1.35 guilders, and the Chinese workers were paid in dollars. Happily for them: in inland China they were not aware of this, so the miners still got more dollars for their guilders (p. 163). Etc.

16 J. Loudon, p. 45. Dekker and Baron Van Tuyll are Loudon's Dutch assistant and boss, respectively. Later the bookkeeper of BM was sent to Singapore to recruit Chinese: he came back on a ship with 150 Chinese sinkehs, 40 miners from Malacca, etc. (Id., p. 58). Chinese people came in small boats from Malacca to Billiton (p. 62). Loudon repeated here that the Hokloh Chinese 'were the worst kind of people, terribly lazy, opium addicts and thieves who all belong to secret societies ...' (Idem, p. 62).

17 Idem, p. 67. On the next page L. mentions himself the reason for getting wounds on the legs: 'The most serious sicknesses were wounds on the legs, which usually started with very small unimportant sores, mostly got by felling trees in the woods of the [mining] areas; soon they are transformed in the most hideous wounds; they end up with cold fire and death' (Idem, p. 68, 69). He never thinks about shoes for the workforce or covering their legs: that cost money, and apparently Chinese lives were deemed worthless. 
the "private" interests, in this case the House of Orange and related aristocratic shareholders. The latter were not exactly the best examples of "private" interests. This row led to the dismissal of the Minister of Colonies, who defended the Royal purse, but BM did not become nationalized.

Indeed, from the beginning this (semi)private character was jeopardized.

Time and again De Lange argued for the support of BM as a state enterprise: from the first visit of Loudon, he was accompanied by state-mining engineers and warships; the contract envisaged that the BM administrators had official police authority, etc. ${ }^{18}$ This was particularly important for the virulent opium smuggling: the administrators did not protect the opium leaseholder enough, but argued, 'the cheaper the opium, the better for the Chinese miners' ('better' here means: the more they buy, the more I gain).

Because a prince and important aristocrats were involved in BM, supervision by the state was neglected. This happened even in the sense that a quarter of the island was given to BM every time; by 1861 the whole island was BM property; only the rich deposits were mined; much less than $10 \%$ of the net profit was no longer paid to the state; the King intervened time and again in favour of BM, etc. ${ }^{19}$ All this was the subject of the row in the 1890 s.

\section{The Opium Business of Billiton}

In the BM memorial book in 1922, it states that BM did everything to combat the use of opium among the miners. ${ }^{20}$ It was the mantra repeated by all authorities at the time. What is hidden behind it looks much less pious, however.

It is remarkable that no explanation is given for the 12 million guilders paid (see table above) for the opium lease, an amount mentioned in this memorial book. The title of this table is misleading (therefore the quotation marks) which tries to suggest that the district was not BM itself from 1861. Who thon on the island of Billiton paid the Dutch government this fabulous amount, and what was the relationship between leaser BM and its "customers"? The memorial author involuntary gives us a small clue to

\footnotetext{
18 G. de Lange, p. 6, 7 .

19 Idem, p. 9 ff., p. $20 \mathrm{ff}$

20 J. Mollema, p. 167.
} 
an appropriate answer. He writes about the alleged Chinese inclination to gambling and opium smoking:

Well, it is true that even a substantial use of opium is not as morally and physically devastating as the alcohol misuse of the Europeans. However, the very expensive opium as luxury expense is a too large part of the budget of the miner (one hoon, which is one pipe, costs 22 cents).... The possibility to save money becomes, therefore, for the weak brothers so difficult that the aim of the emigration to a foreign country is missed. ${ }^{21}$

Above I mentioned that the miner is paid on average one guilder a day; one hoon is, therefore, more than $1 / 5^{\text {th }}$ of this wage. There is, however, a rule that in official opium dens (including the one on Banca and why not on Billiton), the minimum quantity for consumption was two hoons = $1 / 5$ o tahil. In this case, the BM consumer already smoked away nearly half of his daily wage.

Next, because he is paid once a year, "somebody" gets into debt and another claims the annual wage. This must be the mystery behind the difference between what the miner receives on paper and in reality, both documented in the memorial book. That must also be the reason that the miner returns to China after three years, having received only 130 guilders a year. Even for those days a bare minimum for bad work, acceptable only for the migrating destitutes in Southeast Asia.

The receiver of the rest must be the official government leaseholder, BM on Billiton. This company apparently earned a lot of money to addict its own miners, a kind of truck system. ${ }^{22}$ At the beginning of the 19th-century, it was not uncommon in the industrial cities of Europe. For the Chinese immigrant miner who wanted to go back to his village in China, the reality was given in the popular song “... I can't go; I owe my soul to the company store" ('Sixteen Tons').

From the earlier history of BM, the problem was similar. The BM pioneer Loudon understood perfectly well the classic Banca situation in which the Dutch in Batavia delivered and leased the opium:

The leases of opium, pawnshops and liquor concerned those of Toboalie on Banca. The major of the Chinese in Muntok, who is the main leasee, leased himself to somebody on Billiton who paid him 1800 guilders per year. ${ }^{23}$

\footnotetext{
21 Idem, p. 167.

22 See Robert Elson's contribution to N. Tarling (ed.), vol. 2-1, p. 143-144, 148.

23 J. Loudon, p. 18.
} 
Loudon does not inform the reader who this 'somebody' is. He himself used laudanum as a medicine on Billiton, which he must have purchased elsewhere. ${ }^{24}$ The highly lethal character of the labor and a corrupting influence of the European administrators made opium smoking into a necessity. Loudon's hypocrisy is quite remarkable. That people praise themselves in their autobiography later, certainly vain people like Loudon, is understandable. The way he is doing this is not.

In $185^{2}$ he knew how the opium business was organized and exploited by his own administrators; thirty years later he also knew from experience how bad opium was in every respect, and also thanks to several Dutch critics. In retrospect, he had to legitimize his behavior and wrote that in March $185^{2}$ he asked Batavia to prohibit the import and distribution of opium on Billiton:

The aim of this was purely philanthropic. What happened, however? We did not envisage that one needed the means to realize an aim and to vindicate a prohibition. Those means were not available on Billiton, and this open island became poisoned with opium from all sides. Opium became so cheap that nearly all Chinese, who never smoked opium ... became addicts [opiumschuivers]. Therefore, I was obliged later to ask the Government to introduce the opium -lease on Billiton ... ${ }^{25}$

Loudon "forgot" not only that the opium lease already existed on Banca (and through this somehow on Billiton); he was probably misled by the new Batavia plan to introduce an Opiumregie in the 188 os. In this case he did not realize what he was talking about: the Opiumregie was worse than the evil, as is shown below.

Loudon, furthermore, "forgot" that his own administrators had police authority (which was an illegitimate exercise of authority by a private firm, but that is not the problem here); he, Loudon, personally had the means to prohibit it, but he did not. A few sentences further, he even bluntly denied that his administrators had this police power (it existed, according to him, only on Banca), the subject of one of the big controversies in the Dutch Parliament at the time! ${ }^{26}$

24 Idem, p. 44.

25 Idem, p. 57.

26 This Loudon must have lost his mind in 1883 since he, first, mentions (Idem, p. 58) that his administrators 'were no Government officials!' (italics and exclamation mark from Loudon, H.D.). Exactly fourteen sentences later he wrote: that the Government '... decided under certain conditions to provide the administrators of the company with the same police power ... as on Banca ...' In addition, if he was in need of authority, there were many Dutch military on Billiton (as well as on Banca): the army and navy were always mobilized 
The French medical doctor, Georges Thibout, illustrated the misery of the opium addict in 1912:

Many individuals even prefer opium over liberty. The Chinese who work on Billiton to harvest pepper or work in the mines are treated in fact as slaves during the four or five years of their contract. When they give way to the temptation of the small houses along the border of the works where they can find opium, they cannot leave and lose all hope of liberation for the rest of their life. ${ }^{27}$

In short: like dealing in people, like exploiting people for a miserable slavery existence, Loudon and the BM management were also in favor of opium to discipline and silence opposition among the work force, but also to recoup part of the wages through their own opium shop. ${ }^{28}$

against opium smugglers. Loudon himself used the available military to chase Malacca Chinese (p. 63).

27 G. Thibout, p. 91.

28 In the administration of the Opiumregie, this difference between Banca and Billiton is clearly shown through the difference between the licensed and non-licensed opium deliveries on Banca and Billiton. See Commission d'Enquête sur le Contrôle de l'Opium, vol. 2, p. $211 \mathrm{ff}$. for 1928 and below in the section on the Outer Districts-Opiumregie for 1930. 